\title{
A Glimmer of Hope for Three Generations of People Living with Disability
}

\author{
Shuo Cheng
}

\section{Interview with the Grandfather of Miss F}

F, female, only child, born in 1997. Mild intellectual disability. In 2015, after graduating from a special education school-Sunshine School in Huangpu District, Shanghai, she was enrolled in the Junior Vocational Technical School for special education students in Changning District, Shanghai. In 2017, she was admitted into a spare-time university for ordinary people in Shanghai, majoring in hotel management.

Interviewee: Grandfather of Miss F

Interviewer and writer: Shuo Cheng

Interview dates: November 17, 2016 and May 7, 2017

Interview place: Miss F's home

\section{Grandfather and Grandmother Got Married}

Q: Nice to meet you. Could you please tell me how you met your wife?

Grandfather: We were introduced by one of our managers. We worked in the same toy factory, where I was at the main workshop of the factory, and she at a subordinate "Happy Toy Production Team" in the subdistrict, working on tasks assigned by our factory.

Q: Did you live in the same area?

Grandfather: Yes. We're both locals here. We originally came from Nanshi District. Later, according to the new division of the district, she lived in Huangpu District, while my house was in Pudong District.

Q: When was Miss F's mother born?

\footnotetext{
S. Cheng $(\varangle)$

East China Normal University, 3663 Zhongshan Bei Ro, Shanghai 200062, China 
Grandfather: My daughter was born in 1979, a beautiful baby back then. But it wasn't until she began school that we found out about her disabilities in learning.

Q: Did you and your wife consult a doctor?

Grandfather: Of course. We went to a lot of hospitals. Actually, this has something to do with my wife. She hid her condition of mild epilepsy from me before our marriage and took pills in secret while pregnant. It wasn't until the child was born and she went through a seizure that I learned about it. We called the disease "Yang Dian Feng" back then in Shanghai, literally "sheep-vesania-craziness" and now "epilepsy."

Q: How did you feel when you found out about it?

Grandfather: There wasn't any advanced technology. I knew nothing about genetics, either. So, I didn't think much about it. I was simply determined to raise my daughter well, without thinking about getting a divorce.

Q: Has your wife's condition improved over time?

Grandfather: She still has epilepsy, and it got even worse after the birth of my daughter.

Q: Was she able to continue working?

Grandfather: Yes. After a short while when the seizure episode was over, she was back to her normal self and could carry on working.

Q: Have you always been working at the toy factory?

Grandfather: Yes, we were there until retirement.

Q: When did you retire?

Grandfather: Both of us retired at 50 .

Q: When did your wife pass away?

Grandfather: She wasn't in a good shape because of her epilepsy. She passed away in January 2011. It never rains, but pours. After her death, there were tragic events one after another.

\section{The Mom Who Loves to Run Away}

Q: What was it like when your daughter was born?

Grandfather: She was perfectly normal at birth. She was lively, smart, and naughty, just like any other kid.

Q: Did she go to a kindergarten?

Grandfather: Yes. It was in the neighborhood.

Q: Did you notice anything different about her at that time?

Grandfather: No, we didn't notice anything until she was in primary school.

Q: How old was she when she went to primary school?

Grandfather: Seven years old. Everything was normal during the first one and half years. But then, by the second semester of the second grade, her teacher told us that she had trouble catching up with the rest of the class, for she had difficulties in reading and memorizing even the simplest things. Considering she was quite naughty, we assumed that she had ADHD. We sought for a treatment everywhere for nearly a year, but it was all in vain. 
By the third grade, her teacher suggested that she should drop out, saying that there was no use for her to stay in school. I would never let this happen whatever the situation was, so I continued to seek medical treatments. We first went to the Huadong Hospital. A professor from East China Normal University also ran a test on her. The result indicated mental deficiency. But still, I couldn't get a clear picture after all these efforts. Anyway, since the school refused to allow her to attend classes, I could only go to the educational bureau to file a complaint. If my daughter's condition was confirmed, she could be transferred accordingly with help or even to school for children with intellectual disabilities. But like anyone else, she should never be deprived of the right to education.

In response to my complaints, the education bureau allowed her to attend classes without having to repeat a year. She just went to the school every morning and came back home after school. In the meantime, we continued to seek a cure. Later, we consulted an ADHD specialist in the Maternal and Child Care Service Center in Nanshi District. The doctor went through our family history and concluded that her condition was genetic, stemming from her mother's side. It was further compounded by the medication for epilepsy. It was then that I realized the extremely detrimental effects of these pills on children.

By the fifth grade, she couldn't catch up with her classmates anymore. As she grew older, she often went out and wouldn't come back home. I frequented the police station, but the police couldn't find her, either. Every time, she came back on her own. Alas...

Q: When did she start running away?

Grandfather: After she stopped going to school. Maybe in her teenage years.

Q: How often was it? How long would she stay away?

Grandfather: Quite frequently. In the end, even the police stopped trying. We all knew that she would return eventually. She would stay away for long, sometimes even for months.

Q: You must have been very worried about her.

Grandfather: Indeed, but there's no use in worrying. She wanted to leave. There was nothing we could do. In some cases, we asked her to clean the spittoon at the required spot outside the house, while she would leave it outside the door and run away. In another case, we told her not to run away again during the gathering of relatives and friends in the Spring Festival. She made a promise, but disappeared a moment later. It seemed as if it was out of her control.

Q: Would she tell you what happened to her when she was away?

Grandfather: No. She would do whatever she wanted once she ran away. If caught by the police, she would give them our address so that I could pick her up.

Q: What were usually the reasons for her arrest?

Grandfather: Mainly her involvement with men. Society was quite chaotic back then. Not knowing her condition, some bad guys would trick her into having relations with them by buying her food and things. Of course, there were also good people who brought her home.

Q: When things like this happened, was it often found out by the police? 
Grandfather: Some were reported by others, some were discovered by the police, and some were reported by herself.

Q: She knew she should go to the police?

Grandfather: Yes, as she grew older, she knew.

Q: Have you taken any measures to address the result of her possible relations with other men?

Grandfather: At that time, we were quite ignorant. There were fewer contraceptive measures too.

Q: As far as I know, some families choose surgeries, like sterilization, to prevent pregnancies. What's your view on that?

Grandfather: She was too young to undergo that surgery (voice raised, looked more vigilant). She wasn't even fully developed physically. Previously, she wouldn't get pregnant even if she had sexual relations. We never thought about contraceptives. But when she was 18, she came back once after a couple of months with a big belly, already 6-7 months into her pregnancy. By then, abortion was obviously not an option. She had to give birth to the child, who is my granddaughter.

Q: Did your daughter know that she was pregnant? Did she provide any information on the father?

Grandfather: Of course, she knew. That's why she came back, but she had no idea who the father was.

Q: Did your daughter take care of the baby after she gave birth?

Grandfather: Basically, it was me and my wife. My daughter was incapable of that. Nonetheless, my granddaughter was very close to her mother. Despite the birth of a child, my daughter still couldn't control herself. She would run away just like before, sometimes for months on end. This way, she couldn't take good care of the child at all.

I even thought about asking the police to lock her in jail for 3 years so that she can finally "settle" down, but there were no legitimate grounds for them to do so. Once, she was caught stealing money from schoolbags in a university by the police, but they could only ask me to take her home without sentence after learning about her condition.

Q: Did the stealing stop afterwards?

Grandfather: Yes. Knowing that she might be sentenced, she didn't dare steal again, but she still knew nothing about chastity. She just led a free life when she wandered around. I've done my utmost to regulate her and prevent her from making a mess outside, but to no avail. Locking or tying her up would be breaking the law. In the end, we could only let her be. Alas...I lost all hope. She would run away when we were still having lunch and talking. The entire family would worry to death; our relatives and friends would also report to the police and look for her. At last, even the police were out of solutions. We had to give up as well.

Q: What would she normally do at home?

Grandfather: She would just eat and play. There was nothing that she could do. No proper business, basically.

Q: Did she often talk to you? 
Grandfather: Yes, but it was not like what it is today. We were quite busy, so we just tried to talk her into staying at home and stopping wandering outside, etc. Although she said yes, she still couldn't control herself.

Q: Did she understand all that was told to her?

Grandfather: Yes, she understood, but she was illiterate. She didn't know how to write her own name. She could understand what you said, and she could speak to you, but she would be confused if the conversation was extended. In her thirties, she got sick while she was away and passed away after unsuccessful treatment.

Q: What did she die of?

Grandfather: Tuberculosis.

Q: When did she pass away?

Grandfather: September of 2009.

\section{Being Registered for Hukou at Age of Eight}

Q: Could you please tell me more about the situation when your granddaughter was born?

Grandfather: At that time, we lived in a shanty town with poor living conditions. My daughter came back pregnant, but she couldn't be blamed. It was already too late for induced labor. Fortunately, she gave birth to baby F smoothly in December of 1997 thanks to her good health. The whole process was short. I remembered the surgery could cost over 3,000 yuan. I only paid 1,000 yuan and got her discharged as we weren't well off.

Q: Did they find something wrong with Miss F in her physical examinations?

Grandfather: Absolutely nothing. She was an adorable baby, and as pretty as her mom. We didn't find anything wrong with her.

Q: Was she healthy?

Grandfather: Generally speaking, she was healthy without any serious diseases. She received all the vaccinations required at school, but she did tend to have a fever. When she was 2 years old, she had a high fever. One doctor said this was pneumonia and an X-ray was needed. Feeling that I was being fooled, I took her to another hospital, where she was diagnosed with only a virulent cold. She recovered after taking some medications.

Q: Who brought her up mainly?

Grandfather: It was me. Her mother was not around most of the time. Her grandmother was weak and received little education; she couldn't take care of a baby.

Q: Did Miss F go to a kindergarten?

Grandfather: No. We didn't know about her father, so she couldn't be registered as a permanent resident.

Q: Did it affect her in other ways? 
Grandfather: No. She hadn't started school yet. I was basically with her all the time, feeding her, playing with her, taking her around, and sometimes teaching her basic things such as simple songs and numbers.

When she was 9 years old, ${ }^{1}$ there was a new policy whereby anyone could apply for a household registration regardless of the circumstances. This way, she could be accepted by the schools. To get it done, I prepared all the documents, and went through all the administrative procedures in the education bureau and municipal authorities, etc. In the end, I succeeded.

Q: You went through all the procedures as required by the policy?

Grandfather: Yes, totally. I had neither resources nor connections.

Q: Did you learn about this policy yourself or did someone else tell you about it?

Grandfather: Someone told me, but I also knew a little about it. Everyone knew, as word got around.

Q: Do you remember which policy it was specifically?

Grandfather: I remember that it allowed a child to be registered in the household record of direct relatives, either those from the mother's side or the father's side. ${ }^{2} \mathrm{~F}$ is registered in her maternal grandmother's household. The policy remains the same now, I think.

\section{Adored by Teachers and Classmates Alike}

Q: When did Miss F start primary school?

Grandfather: When she was nine, ${ }^{3}$ when the household registration was done. I applied for the Guangming Primary School, but after the interview, the dean of students suggested that my girl might need an IQ test. A special education school might be an option if the result indicated the need for it.

So, we went to the No. 6 People's Hospital. Upon learning about the test results, I could hardly remain standing. My heart sank. Just like her mother, she also suffered from an intellectual disability. Though she was slightly better than her mother, it didn't make me feel any better. I knew she wouldn't be able to attend a normal school. Later, she was enrolled into the Sunshine School for intellectually disabled students on Beijing West Road. It was far from home. I had to drive her there in the morning and pick her up after school in my mobility car for the disabled while carrying on with my own business. Sometimes, her mother would also pick her up, but her grandmother couldn't.

$\mathrm{Q}$ : Was everything okay when her mom came to pick her up?

\footnotetext{
${ }^{1}$ Nominal age. The actual age should be eight.

${ }^{2}$ According to Article 8, Chap. 2 of the Regulations of Shanghai on Management of Registered Permanent Residence, implemented since July 1, 2005, "The birth of a newborn baby can be registered in his or her father's or mother's household registration record in this municipality as a non-agricultural permanent resident".

${ }^{3}$ Actual age.
} 
Grandfather: It was okay. Despite her intellectual disability, she was good at finding her way around town. She might not know the name of the road, but she remembered clearly the routes and knew which bus to take and how to transfer.

Q: How long did it take to bring Miss F to school and back?

Grandfather: About $2 \mathrm{~h}$.

Q: When was she able to go to school without your company?

Grandfather: Since her second grade. At that time, a teacher surnamed Xie, the teacher in charge of her class, also lived nearby in Pudong. So, the teacher would take my granddaughter to school and take her home after work. I'll always remember the teacher's kindness.

Q: How was it when she was in primary school?

Grandfather: She was pretty good. Her teachers all liked her.

Q: What courses did she take?

Grandfather: The curriculum for different grades was different. Basic courses such as Chinese, math, and IT were all offered. A very good school, actually. I remembered she said she learned how to use the computer at school. At first, I didn't buy it. Later, it turned out she was pretty good at it after I bought one for her.

She learned many things at school, and was good at some subjects, apart from singing. Dancing and sports are her strengths. I remembered that she put on an amazing performance at a dancing show organized by her school in a square on Nanjing Road. The audience was deeply moved; some journalists even came to interview her. This was surprising to me.

In terms of academic courses, however, she barely matched normal students. Her math was particularly weak. Other students could do multiplication and reduction, while she could only do the basic one-digit calculations and had a hard time learning multiplication. As a child, she couldn't go out grocery shopping simply because she couldn't do the math.

She was not bad at Chinese. She could even draft her own speeches. Orally, she could understand basic conversations, but found it hard to discuss things in depth. Still, she was so much better than her mom. Sometimes, I think she's even smarter than me. She's a quick self-learner with phones and computers, while I am not.

Q: How did she get along with her teachers and classmates?

Grandfather: They got along quite well. Younger students would call her sister. All the students from the first grade to the ninth knew about her and adored her. She also assisted the teachers in a lot of things.

Q: How long did she study in the special education school?

Grandfather: Nine years, as required by the policy of 9-year compulsory education.

Q: Did she assume any role in her class?

Grandfather: Yes, such as the Young Pioneer Group Chief, flag raiser, and class monitor.

Q: How was she admitted into the Junior Vocational Technical School after graduation from primary school?

Grandfather: She applied for it and passed the interview. In fact, she was already known to the school officials during their meetings. Her excellent performance at school and the prizes she won had already caught their attention. 


\section{Not Afraid of Hardship in Her Training for Special Olympics}

Grandfather: F performed pretty well at school, especially during the 2007 Special Olympics.

In a sense, she was much luckier than if she continued her studies at a normal school. In the Sunshine School, she learned quickly, and was very capable. Good opportunities always came to her first. Once, for example, she participated in a competition as a substitute. The school noticed that she became champion or runnerup in many competitions, showing strong stamina. That was how, in the following year, she was selected to receive training in roller skating in Heilongjiang Province for the 2007 Special Olympics. Finally, she won a silver medal. She also competed in swimming. From then on, I started to have more confidence in her and see a glimmer of hope. I was happy for her (see Fig. 1).

Q: How old was she when she went to Heilongjiang Province?

Grandfather: About 11 years old.

Q: Was she afraid of being so far away from home?

Grandfather: No. This was good. Also, I would contact her regularly through mobile phone at that time.

Q: You said that she was good at a variety of sports. Did she receive any special training for that when she was little?

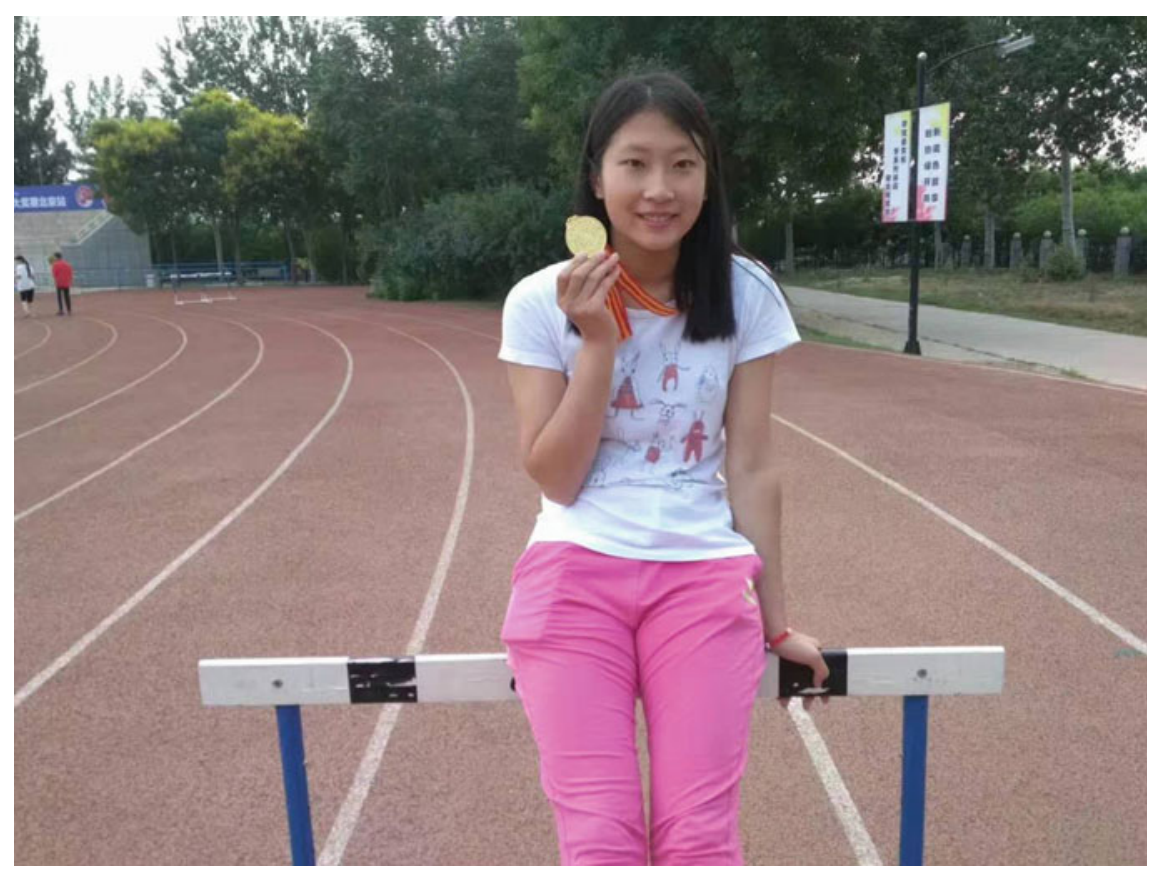

Fig. 1 Miss F on the school playground with her medal 
Grandfather: No, she learned them later on.

Q: I imagine these achievements were no easy feat?

Grandfather: Indeed. She took swimming classes at school. A professional swimming pool was also rented for practice. So, swimming became one of her strong suits as well. She competed a lot, and won a lot of medals.

Q: Did she practice every day while learning to swim?

Grandfather: Basically, every day. I remember the intensive training were all organized at Tera Wellness Club on Henan South Road, a well-equipped center. The training was hard, but she was willing to make the effort. Sometimes, she had to travel across the country for such training. Physical exercises, such as stair running and push-ups, made everyone sweat all over. F would never complain about the hardship as everyone else did, but said, "I love sports. I'm willing to do this." I guess this was probably the reason why the teachers liked her.

Q: Apart from extracurricular training, did she have daily training on campus?

Grandfather: No. At school, she just attended the lessons.

Q: Have you noticed any difference in Miss F since her participation in sports?

Grandfather: She became more confident and healthier. She tended to have colds and fevers, but now she seldom falls ill. This is the benefit of exercises. The only thing is that she still has rhinitis.

Q: What's the impact of Special Olympics on Miss F?

Grandfather: It had a huge, huge influence. Otherwise, she couldn't have become so joyful; she wouldn't have reached what she has today. More importantly, Special Olympics allows her to do what she loves. She has always been diligent and tenacious. She gains confidence and courage through the game. This is the key.

$\mathrm{Q}$ : Did you raise her to be this tenacious?

Grandfather: To be frank, we didn't do much. I myself received only basic education. I'm not in the best position to teach her. She may have become tenacious for two reasons: her interest in and passion for sports, and her commitment to our family. She wants to create a better life for everyone. Aside from the encouragement from the school and society, she was also inspired by the theme of Special OlympicsI know I can! F is becoming more mature. She strives for the honor of her school, which wins her admiration from all of her teachers. What we have given her is simply encouragement and support.

\section{Become Independent at a Young Age, Sticking Together with Grandad}

Q: She must have learned how to take care of herself at a very young age, such as getting dressed and feeding herself, didn't she?

Grandfather: Yes. We didn't have to teach her. She was quite independent. She would wake up in the morning and go to school on her own. She loved learning, which was good. Take going to school as an example. She had to get up really early, 
take Bus No. 451, and then transfer at the People's square. The journey took over $2 \mathrm{~h}$, but she never complained and never needed us to wake her up or urge her to go to school.

Q: When did she learn to do housework?

Grandfather: I was not the best example in this aspect. I spoiled her a bit and didn't ask her to do anything when she was young, since she's my only granddaughter and also suffers from an intellectual disability. By the fifth grade, she was able to help around the house, washing vegetables, sweeping the floor, going grocery shopping, and so on. She got better by then. By the time she was in middle school in her teenage years, she could put what she learned at school into practice and prepared meals for us.

Q: It seems that she is really independent. Did you teach her to be this way?

Grandfather: Not intentionally, but I am really happy that she understood what I said about how to be a responsible person. Now that she has grown up, she knows that I don't have an easy life. She does what she can to help me, such as learning how to cook and prepare for simple meals, and taking care of the family. She's very thoughtful.

She never gets me to worry too much. She tells me about her daily life, like where she is, at school or on the way back home, what she is doing, when her class finishes, and she'll go to swimming training at 4:30, etc. This morning, she was in Chongming. She also sent me a message asking if I've had my breakfast and if I wanted to have a video chat with her.

Q: Do you miss her, as she is not home most of the time?

Grandfather: Of course, but now with the mobile phone, we can call each other, or have a video call. I'm happy with that.

\section{Missing Mom on Mother's Day}

Q: Apart from housework, does she have heart-to-heart talks with you?

Grandfather: I don't know if she has something on her mind, but I can feel that she's down occasionally. She knew she had no father and her mother has gone. She was particularly sad and not willing to talk on Mother's Day.

Q: Have you ever talked to her about her parents?

Grandfather: Yes. She knew something about it. Her mom was still alive when she was in primary school, so she knew about her mother's life, personalities, disease, and death.

Q: Does she know anything about her dad?

Grandfather: No, because he was never in her life.

Q: Has she ever asked about him?

Grandfather: Yes. I explained to her that it was due to her mother's condition.

Q: Could she understand?

Grandfather: Yes, she could. I told her there was no point in finding out who was to blame. She understood it. However, I could still feel that she was a bit sad, particularly 
when she was in primary school. She would cry and get emotional on Mother's Day, or whenever the word "mother" was mentioned or appeared in textbooks. It was a sore spot for her. Now she can handle it better. In contrast, she wasn't as emotional at the idea of father, as she never knew her father, and her grandad is like a father to her.

Q: Have you tried to get through to her?

Grandfather: Sometimes I will, but somethings are just too difficult to explain, and she can be really stubborn.

Q: What was she stubborn about?

Grandfather: Knowing that I was quite tight with money, she wouldn't ask for any money unless it was absolutely necessary. Sometimes, depending on her needs, I would give her more and tell her how to control the spending. Emotionally, she mainly felt bad on the topic of her parents, which was understandable. It was a rebellious stage during her adolescence. She became quick-tempered and worked off her anger on teachers and family if she couldn't figure out something. Teachers knew this. They would also talk to me about concerns over her mental health.

Q: So, you talked to the teachers?

Grandfather: Yes. Mr. Shao, her teacher in charge, once came to me. He was kind-hearted. He cared about her, while kept in touch with us, informing us of her performance at school. When $\mathrm{F}$ got into trouble in her rebellious years, I would communicate with Mr. Shao. He showed great understanding and helped her through that phase.

I think it's more challenging to be a teacher in special education schools than in normal ones. Teachers in normal schools can focus on teaching. Talks with disobedient students can make them behave. But in special education schools, teachers have to be responsible for a whole range of issues from students' intellectual disabilities to emotions. Once, in the primary school, a student in F's class approached a teacher with a knife. When attempting to stop the student, she accidentally got hurt and was immediately sent to the hospital.

Q: How did you feel about this incident?

Grandfather: I didn't take it seriously, nor did I argue with the school or the teacher. I believe teachers and parents should be complementary to each other. In this way, teachers can become more confident in their work. It's meaningless and unnecessary to blame teachers for risks of security or disfigurement. Helping the teachers is helping your child. To be honest, families of children with intellectual disability are under immense pressure. No one wants to have a child like this. It's important to put yourself in other's shoes. As for teachers, their work is already challenging as it is, we can't put extra pressure on them.

Q: Was there any cause to her rebellious period?

Grandfather: Deep down, I believe it was probably due to her parents. Though she wouldn't say it out loud or admitted that she was unhappy, she would feel wronged and upset if I brought it up. She could be very stubborn. She has a personality.

Q: How long did it last?

Grandfather: Only half a month. She was about 17 at that time. She would ignore you for no reason. Sometimes, she would cry and throw a tantrum. If a teacher blamed 
her, she would talk back. Of course, she knew she was wrong afterwards and would greet the teacher when they met again. This is just normal for a growing teenager.

\section{Mobile Phone and Friends}

Q: Apart from sports and study, does she have other hobbies in her spare time, such as reading, and watching movies?

Grandfather: She doesn't watch movies. She enjoys listening to music, watching animations, and surfing the Internet on her phone. At home, she loves to do housework, like washing the dishes and cooking.

When she was little, she would pester me to take her outside for a walk or to the supermarket. Now as she grows older, she prefers staying at home. Sometimes, I urge her to go hang out with friends and talk to them, but she won't. However, if there is a sports event, she becomes energetic again. She will go to training and never complain about the difficulties.

Q: Does she have any friends?

Grandfather: Yes, she often hangs out with an orphan girl who will also take the college entrance examination. I heard that the girl can go work for KFC, but she doesn't want to. They receive training together, and have parties celebrating birthdays and graduation. They have developed their own circle of friends.

\section{Grandfather's Foot Impairment and Hardship in Life}

Q: What is the mobility car that you just mentioned?

Grandfather: It's a car specifically designed for the disabled. We paid for the car and the government would give us the license plate. I can't remember exactly the year, but the government suddenly didn't allow these cars to be used for business purposes on the road, claiming that too many of them affected the traffic. The government recycled all of them at the original price. After that, the Shanghai Disabled Persons' Federation (DPF) designed a new model according to its integrated planning. The total subsidy from the government for this was 6,000 yuan. You could either get your own car recycled by the government and receive 6,000 yuan, or if you still wanted to drive it, you could buy one from the DPF at the price of 5,000 yuan, for example, and receive the rest of the money, 1,000 yuan.

Q: You also have disabilities?

Grandfather: Yes, I have trouble walking because of my feet problems.

$\mathrm{Q}$ : Could you please tell me more about doing business with the mobility cars for the disabled?

Grandfather: Back then, people looked for business opportunities everywhere. The Shiliupu Pier on the Bund was famous. It was accessible to major ports in 
Ningbo City, Zhejiang Province and Jiangsu Province, etc. Since there weren't highspeed trains, ships were the means of transportation. The ships would be anchored at the passenger terminal with a fixed time schedule. We would be there waiting for people, like the cart drivers in the old days. Then we negotiated the price with our passenger, like 10 yuan for City God Temple. If the price was agreed, we would take them to their destination. The whole market was not properly regulated. Even people without a disability certificate could drive around in cars for the disabled, looking for business. Later, the government ruled that vehicles for persons with disability shall only be used for facilitating mobility, not for business purposes. Only people with lower-limb disabilities could drive the cars to make their life easier. The government confiscated the cars without proper documentation and restored order to the road.

My car was a good one. It cost 5,000 yuan. I got it recycled by the government for 6,000 yuan, after it was banned from being used for business.

Q: What kind of car was it?

Grandfather: It was three-wheeled and petrol-driven, and it could be started easily just like a motorcycle. Now I regret that I didn't buy a new one at that time.

Q: Why?

Grandfather: It's convenient for travelling. As long as you do nothing illegal, this type of car, with a petrol subsidy from the government, is allowed on the roads across the whole country. One can drive it across the Huangpu River or even to Beijing. This is because relevant polices exist to protect the rights of persons with disabilities.

Q: Do you usually go out for a change of mood?

Grandfather: Yes, I often talk with my friends about life over dinners, but I would leave at the mention of housing. This is my biggest disappointment and regret. I used to have an apartment, but when we were relocated by the government, I chose the compensation of cash, instead of an apartment. The amount was less than 100,000 yuan. We also planned to buy a house with it, but didn't act immediately, assuming the housing price wouldn't go up. Surprisingly, the price skyrocketed simply within a few months and never decreased. It became totally unaffordable. I regret my choice back then. It's miserable for a family without a house nowadays.

Q: Why did you choose to take the money?

Grandfather: It happened that my wife and my daughter were sick at that time. I needed the money for their treatment, which really cost a lot.

Q: Did you find this current apartment by yourself?

Grandfather: Yes. The monthly rent is only 1,000 yuan currently, but its total area is only more than $70 \mathrm{~m}^{2}$, and the transportation is not convenient. Now the rent in this area has risen to 2,000 yuan. I have to negotiate with the landlord on an acceptable increase before our 3-year agreement expires. Apartments around here are originally low-cost housing for people relocated from Hongkou District and Yangpu District.

Q: Is it big enough for the two of you?

Grandfather: It is okay after a simple renovation.

Q: You have a nice home here. Did your wife also live here?

Grandfather: Yes, but she passed away many years ago. Now, it's only F and me.

Q: Did you go to the local authorities regarding the housing issue? 
Grandfather: No, there's no use. There's nothing they can do about it, either. If F is registered in my household, we can apply for low-income housing, but then again, it costs a lot. The payment and mortgage are complicated as well. In the end, we still have to rely on ourselves. Another possibility is that F may be assigned an apartment if the residents in the area of her household registration are to be relocated. In that way, our situation might improve.

Q: Do you feel any other pressure in life except for housing?

Grandfather: Of course, apart from the 1,000 yuan for the rent, we still need money for F's transportation, meals, and other daily necessities.

Q: What is your major source of income?

Grandfather: I've got a pension and subsistence allowance, and F has subsidies for persons with disabilities, as well as the subsistence allowance.

Q: Does she get paid for her participation in these competitions?

Grandfather: She used to. She could receive more than 1,000 yuan as a bonus and training fee apart from the accommodation and meals covered by the government. Now, these additional subsidies are gone. She only gets a reward for her participation as a token of encouragement. It's kind of like charity, trying to attract public attention to them. Besides, she can receive an annual scholarship of 200 yuan since primary school.

Q: Do you give her some pocket money? How does she spend it?

Grandfather: Yes, I do give her some. She knows we're not well off, so she tries to save money. Of course, certain expenditures, such as transportation fees, cannot be cut back. Sometimes, I give her more to ensure she won't feel short of money and get embarrassed. For example, I gave her some money when she went to Macao, and she brought back some local delicacies for me, like others did. Though I thought it was unnecessary, I didn't blame her since I knew it came from a good place.

\section{Hope for a Better Future}

Q: Have you changed much throughout her growth?

Grandfather: Her growth felt like a roller coaster ride to me. I was happy that she was a perfectly normal baby, but was later devastated by her diagnosis before primary school. Now, I feel elated that she went to school, and went on to win many competitions. There were gloomy days of course, but now there is hope and happiness. Compared with her mother, I am relieved to see how far she has reached. Sometimes, I would think to myself if $\mathrm{F}$ had been a child without disability, she might not have had so many opportunities and achievements, and I wouldn't be so happy now. Once a staff member from the education bureau told me that, since F was an athlete leader of Special Olympics, she could do what she was good at in the future, such as a journalist, or a coach. There is a bright future for her.

Q: Do you think she will get into college?

Grandfather: I think there is chance for her because she is quite good at Chinese. In her spare time, she can write speeches, while I can help her with the delivery and 
expression. This may seem easy, but good delivery of a speech requires certain skills such as how to control pace and rhythm. When introducing ourselves, we should be able to enunciate, articulate, and keep a good pace. I will help her if she encounters any unfamiliar characters.

Q: Miss F works really hard. This is my second interview with you, and I've heard she has already been admitted into college. ${ }^{4}$ Do you support her further studies?

Grandfather: Certainly. It is her wish to go to college, I'll be supportive as always. I don't know what will happen next, but I'll do my utmost to help and support her. I am grateful that the government is doing the same.

Q: Do you have any expectations for her future?

Grandfather: I don't want to put any pressure on her. Her future depends on her choices and actions. I just hope that society and college can give her more opportunities so that it won't be so difficult for her. Before I die, I wish to see that she can live a happy life with good health and a steady job. My concerns now are just her job and marriage. She has to consider these after all. I want to see her get married and be happy.

Q: Society is changing for the better and Miss F is an exceptional and hard-working person. I'm sure all your wishes will come true.

\section{Interview with Miss F's Head Teacher}

Interviewee: Mr. Shao

Interviewer and writer: Shuo Cheng

Interview date: March 9, 2017

Interview place: Junior Vocational Technical School in Changning District, Shanghai

\section{Witnessing Her Grow into an Outgoing and Thoughtful Girl}

Q: Mr. Shao, it's a great pleasure to have this interview with you and talk to you about Miss F.

Teacher: It's alright. This is what I should do as the teacher in charge.

Q: Have you always been the teacher in charge of Miss F's class since she started school here?

Teacher: Yes, I took over her class when she entered the school until her graduation. I know her quite well.

Q: What do you think of her?

\footnotetext{
${ }^{4}$ This part of the conversation was undertaken during the second interview, when $\mathrm{F}$ has already been admitted into a college.
} 
Teacher: Generally speaking, she is thoughtful and careful, and more capable compared with other students. We like students like her.

Q: How has she changed over the past 3 years in the school?

Teacher: She has become much more mature. At first, she had trouble fitting in and was very uptight. Gradually, as she had more interactions with teachers, students, and the management, she became more outgoing, talkative, and capable. Because of her abilities, she was elected as one of the class representatives. She made huge progress while undertaking this role. Her general state is really good.

Q: Now that she fits in well, could she have been a good student if she had studied at a normal school?

Teacher: Children like Miss F do not suffer from severe intellectual disabilities, so they can perform well in our school. But as you know, normal schools focus a lot on academic performance; Miss F is simply no match for students there. The fact that she's been studying in special education schools makes it even harder for her to study in a normal one.

From a different perspective, a normal school is not necessarily the best option for her. Her weaknesses would have been heightened, costing her many opportunities for her better growth. And she couldn't have had the chance to know about Special Olympics, let alone become an athlete leader. The huge support for her would have been impossible. Her current opportunities and achievements are essential for her future development. It's fair to say that the special education school is the best place for her.

Q: I agree with you. Could you elaborate on her difficulties in learning?

Teacher: Generally, her performance has been satisfactory. She is relatively good at Chinese, but not at math. She can only do simple addition and subtraction, but finds it difficult to deal with multiplication and division. it?

Q: For her, it is more important to be able to put things she learned into use, isn't

Teacher: Yes, the ability to apply what she has learned in life would suffice. With mobile phones and calculators, we don't need to force her to learn multiplication or division, but it is still good for her cognitive development to know the basics of math.

\section{Give Full Play to Her Strength and Live to the Fullest}

Q: Does her strength in sports compensate for her weakness in academic performance?

Teacher: You can say that. Compared with academic learning, her strength lies in sports. This gives her more chances to succeed. She started to participate in Special Olympics training and the Special Olympics World Games from a very young age, travelling home and abroad for competitions. This allowed her not only to give full play to her strengths, but also to broaden her horizons, meet more people, and have more experiences as she grew up. For Miss F and her family, this is something to be proud of. I am also proud of being a witness to her success. 
Q: Do you support her in her further development in sports?

Teacher: I always encourage Miss F to pursue what she is good at and interested in. If she intends to take part in certain types of sports, our school will look for the opportunities and resources to support her professional training to pave her way to success. As an athlete leader of Special Olympics, she often gives speeches now. I'll teach her some techniques, and guide her on how to draft a speech, so now she has become quite articulate.

Q: What kind of guidance have you given her?

Teacher: In terms of language abilities, practice makes perfect. It's also important to know how to properly express oneself. So, in practice, I would focus on training her to be more articulate.

Q: Is she able to fit in at school?

Teacher: Yes, she gets along very well with teachers and classmates. With her rich experience in competitions, she now regularly participates in activities and competitions on behalf of our class and our school. She performs very well on stage.

Q: Does she normally take the initiative to talk to you?

Teacher: She would talk to me if something was wrong. But there are things she would keep to herself, which is normal, given that she was going through puberty.

Q: I also heard that she went through a rebellious phase.

Teacher: Yes, there was a short period when she didn't talk much and became very headstrong. But then again, people all go through a mood swing every once in a while. It's the same for people without disabilities.

Q: How did you help her through that phase? Any special measures?

Teacher: Nothing special. I just noticed that something was wrong, so I talked with her to understand what was going on. After some period of adjustment, she was herself again without anybody's help. tion?

Q: How was she doing during the preparation for the college entrance examina-

Teacher: During that period, she studied and reviewed her lessons very hard, taking classes every day. There was great pressure, actually.

Q: Did she encounter any obstacles during the preparation?

Teacher: Math was difficult for her. Although the math test was designed to be much easier, basic concepts were still hard for her.

Q: Do you have any thoughts on or any expectations for her future development?

Teacher: She is really good. She got herself into college on her own. It may not be a major university, but it is a huge success for her. In the future, I hope she can seize every opportunity to play to her strengths and live her life to the fullest. This is our shared hope for her.

Q: Thank you for your best wishes. I also hope that she will continue to be a contributing member of society. 


\title{
Interview with Miss F
}

\author{
Interviewee: Miss F \\ Interviewer and writer: Shuo Cheng \\ Interview date: March 9, 2017 \\ Interview place: Junior Vocational Technical School in Changning District, \\ Shanghai
}

\section{My Teachers and Classmates}

Q: Hello, Miss F. It's a great pleasure to meet you.

F: Nice to meet you, too. Can I call you sister?

Q: Of course, you can call me sister Cheng.

F: Sister Cheng, you look young. Where do you work?

Q: I am still a college student.

F: Where are you studying?

Q: I am studying at the Huadong Normal University. I am on campus in Putuo District. Have you ever been there?

F: No, I've never been there, but I've heard of it. Mr. Li, my gardening teacher, used to be a student there.

Q: Really? Could you tell me something about this teacher?

F: Em... (thinking for a while) My gardening teacher is Mr. Li. He is very kind to me and cares a lot about me. Besides gardening, he also taught me math. He even tutored me in math when I prepared for the college entrance examination. He is an amazing person. He knows so many things and teaches me so much about gardening, like this pot plant (taking the interviewer to a potted plant while talking). He taught me how to remove the weeds and replace flowerpots.

Q: How do you do it exactly?

F: We use a special little shovel to remove the weeds and turn the soil over. Mr. Li told me that there were dos and don'ts. You can't just do whatever you want. You see... (demonstrating while explaining) there are plenty of weeds in this pot. I need to remove them all at their roots so that they won't grow back. These are particularly difficult to get rid of, because they are really thin, and some are deep-rooted. We need to dig deep to take out their roots and not leave any remnants in the soil.

Q: You really know a lot!

F: I learned from the best. He is quite knowledgeable. I still have so much to learn (a little shy). Also, don't forget to replace the flowerpot after getting rid of the weeds.

Q: Really? Why is that?

F: You see that the soil in this pot is kind of whitish, which means it lacks nutrients. We need to flip the soil. If the soil becomes entirely white, then we need to replace it with a special type of soil rich in nutrients.

$\mathrm{Q}$ : What kind of soil is the best? 
F: Soil that is black and damp. This means it is rich in nutrients and water, which helps a plant grow.

Q: How do we flip it?

F: You should be careful not to cut off the roots of the plant. Just turn the soil slowly and gently from the side, layer by layer. You see just like this (demonstrating). When the surface layer has been overturned entirely, use the shovel to press it down a little bit to make it flatter. And that's it.

Q: You are quite an expert!

F: Thank you! I am not as good as Mr. Li actually. He takes care of all the plants and flowers here (taking the interviewer on a tour of the gardening area). He comes here every day to water the plants, remove weeds, and turn over the soil. He is quite meticulous. There is still so much to learn from him!

Q: When did you start to take gardening classes with Mr. Li?

F: Ever since I came to this school. It's been a long time and I've forgotten some of the things that I've learned, but I can always turn to Mr. Li for help. He is always patient with me.

Q: How do you get along with other teachers?

F: They are all kind to me. Mr. Shao has been the teacher in charge of my class ever since I got here. He is kind, patient, and careful. He cares a lot about me.

$\mathrm{Q}:$ Can you give me an example?

F: I can't think of an example at the moment. There are so many. Anyway, he's just very kind to me. Sometimes, he would ask me about my family. If I was in trouble, he would lend me a helping hand. In terms of studies, he encourages me and helps me with math. I am delighted that I can help him and other teachers too, such as managing the class.

Q: So, you're one of the class representatives, aren't you?

F: Yes, I've always been the class monitor.

Q: What does it entail?

F: I am responsible for the discipline, homework, and other tasks assigned by the teachers, such as sending out notices, and attending events on behalf of our class.

Q: I figure you must be quite busy.

F: Sometimes, but I take pleasure in helping teachers. Besides, it gives me an opportunity to improve myself, which is good for me.

Q: That's really positive thinking.

F: I think that all the teachers are nice to me, so I should do something in return, helping them as much as I can.

Q: Do you take the initiative to talk to Mr. Shao?

F: Sometimes I would tell him something and he would also ask me about how my grandad and I are doing, and what's going on in my family. I also tell him about my classmates and things that I experience outside of school. I find it interesting talking to him.

Q: So, you enjoy talking with teachers?

F: Yes, I love it. Mr. Shao is kind-hearted and thoughtful, so I am not afraid of him at all. I can share everything with him.

Q: Do you have many interactions with other teachers? 
F: Of course, I get on well with all the teachers. They all like me.

Q: Do you enjoy attending their lessons? Do you have a favorite subject?

F: I enjoy them a lot. They are good teachers. I've learned so much. My favorite subject is... (hesitant) I don't know. I like them all. If I had to choose, I think I enjoy baking the most, because I get to make delicious and beautiful cookies.

Q: Really? I remember that you want to become a pastry chef, don't you?

F: I have thought about it, but I've just begun with the learning process. I am not sure if I am going to be good at it, but I'll give it my best.

Q: I believe you! What do you learn in baking lessons?

F: We've learned to make many things, including cookies and cakes. There are many things in the textbooks that I'm not able to make. There is still so much to learn (see Fig. 2)

Q: So now you know how to make all of these things? Do you usually practice at home?

F: Almost, but some are particularly difficult. I cook at home, but not so often. I only go back home once a week, since my grandad lives far away. So, I don't have much time.

Q: Do you live on campus except for the weekends?

F: No, I live with the sister of my grandmother. She lives closer to my school, near the City God Temple. It's walking distance to school and more convenient than going back home.

Q: Are you used to living with her? Do you miss your grandad?

F: Yes, I am used to it. I've been living here for a long time. They are all nice to me. I miss my grandad sometimes, but I can always have a video chat with him or send him a message, which helps a lot.

Q: Do you often hang out with your friends?

F: Sometimes, but not often. They have their own things, so it's hard to get together.

Q: Could you tell me something about your friends?

F: I don't have many friends, only a few close ones. They are friendly, and I am really happy spending time with them.

Q: What about your classmates? What do you normally do together?

F: There aren't many classmates. I got to know my friends mostly from training. We watch TV, chat, and sometimes go shopping and play games. It is wonderful.

Q: Do you go out a lot?

F: Not often. I just stay at home after school or on weekends. I'm quite comfortable at home. I would go out if I feel bored.

Q: I also enjoy staying at home, being alone and quiet. Apart from baking, what else do you learn at school?

F: I have specialized courses, including baking, services, and gardening, and also Chinese, math, and English.

Q: Are you happy every day at school?

F: Yes, because I can learn many useful things and all the teachers are kind to me. I can also help them with many things. My life is full.

$\mathrm{Q}$ : What about your classmates? How do you get along with them? 
A Glimmer of Hope for Three Generations of People ...

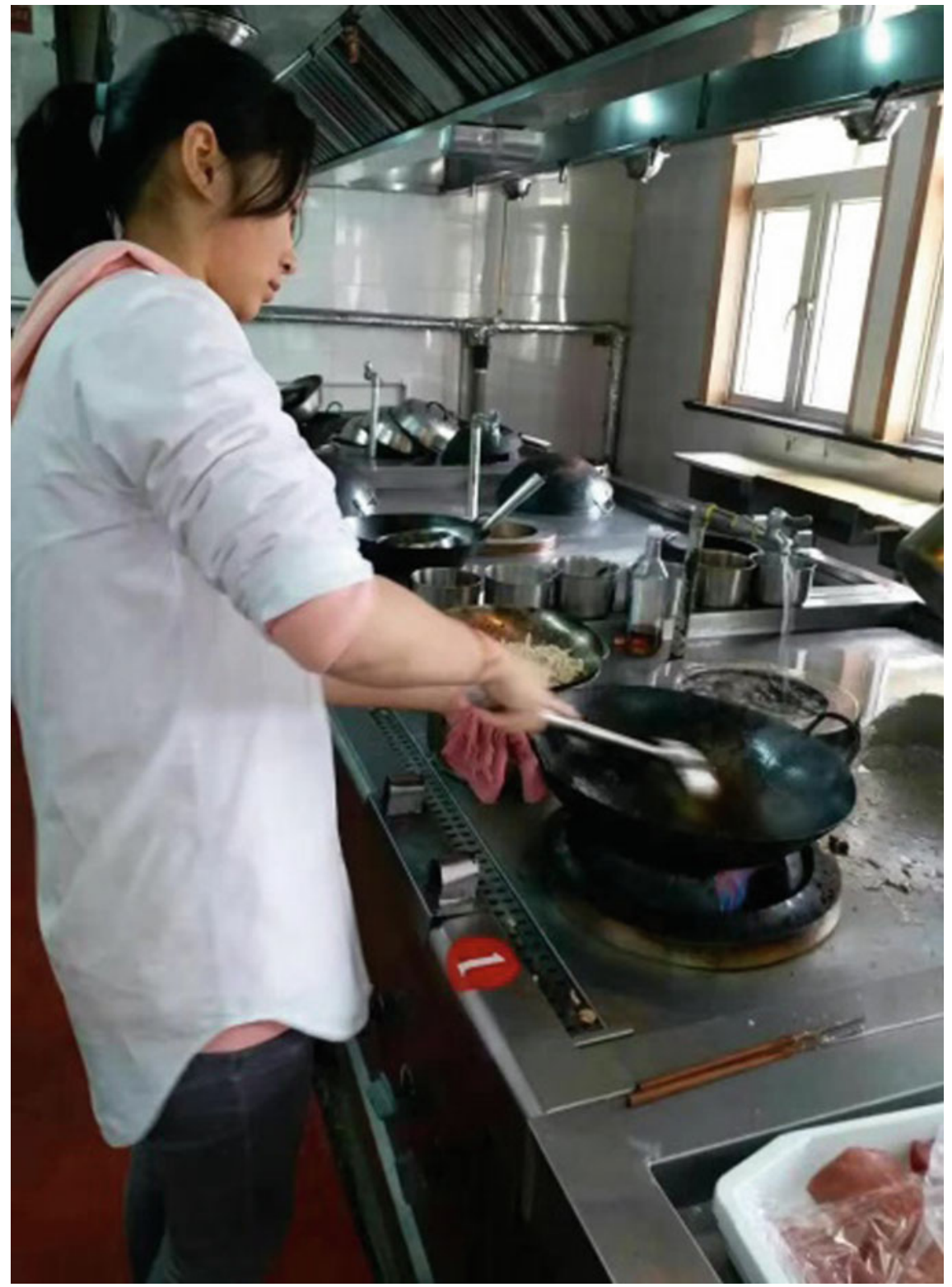

Fig. 2 Miss F in cooking class 
F: My classmates are also friendly, but some of them are disobedient. Some tend to disregard discipline during classes, making it very difficult for teachers.

$\mathrm{Q}$ : Do you usually talk to them or play with them?

F: Not often. There's not that much time. During breaks, I may assist teachers and sometimes I sit at my seat and talk to some of my classmates.

Q: Can you communicate well with your classmates?

F: Basically okay. I think it's fine to chat with them, but there is not much to talk about. Also, the break is short.

\section{Going to College}

Q: You are going to graduate soon, aren't you?

F: Yes. I'll graduate this June. I was admitted into a 3-year college and now I'm taking relevant courses.

Q: Which college?

F: A spare-time university on Shuicheng Road.

Q: Did you get in through the college entrance examination?

F: Yes. The college entrance examination for adults.

Q: What subjects were there in this examination?

F: Mainly Chinese, math, and English.

Q: Did you find it difficult?

F: I was under a lot of pressure at that time. English and math are pretty difficult for me.

Q: How did you prepare for the examination?

F: I attended exam review classes organized at our school.

Q: Who were your teachers?

F: Mr. Li was my math teacher, Ms. Liu was my English teacher, and Ms. Yan was my Chinese teacher. They were all from my school. There were many students attending these kinds of courses.

Q: How did you overcome the difficulties in math?

F: Teachers would show me how to do it step by step. If I still couldn't understand, they would ask me to write it down.

$\mathrm{Q}$ : Did you receive any additional tutoring?

F: No.

Q: Did your teacher in charge give you a lot of encouragement?

F: Yes. He told me to prepare well. In fact, before the exam, I had the option of going to a forum in America or sitting for the college entrance examination. I chose the latter.

$\mathrm{Q}$ : What is your major in college? What courses do you have?

F: I major in hotel management. I have taken a lot of courses such as management science, politics, and so on. I don't remember the titles. On Monday morning, I have Marxism and Xiaoping Deng Theory. In the afternoon, I need to go back to attend courses at the Junior Vocational Technical School. The courses for hotel management 
are scheduled on Friday mornings and I can go back home in the afternoon. From Tuesday to Thursday, I attend specialized courses at the Junior Vocational Technical School.

Q: You mean you have to take courses at two schools?

F: Yes. I have to go to two schools because I haven't graduated yet.

Q: Why do you have classes now? Doesn't the school start in September?

F: Actually, it started in March. I have to learn beforehand just like other students.

Q: So, you are quite busy. Do you have any trouble with your studies?

F: I don't think it is easy. I don't understand some of the things I've read, but teachers will explain things in class. I take notes and read them over afterwards. I think it's much more difficult than what I am learning now.

Q: Ha ha, it is indeed more difficult in college, but I believe that if you try your best, you can do it. I believe you!

F: Thank you for your encouragement. I will do my best!

\section{Observation of Miss F at School}

Observation date: March 9, 2017

Observation place: Junior Vocational Technical School in Changning District, Shanghai

Observer and writer: Shuo Cheng

\begin{tabular}{l|l|l|l}
\hline Time & Activities & Performance of Miss F & Notes \\
\hline 8:20-9:00 & $\begin{array}{l}\text { Horticulture class. } \\
\text { Learning Basic Botany, } \\
\text { such as photosynthesis } \\
\text { and respiration }\end{array}$ & $\begin{array}{l}\text { Miss F was well } \\
\text { prepared and waited } \\
\text { quietly for the teacher to } \\
\text { start. During the lesson, } \\
\text { she was very attentive, } \\
\text { with her eyes always } \\
\text { focused on the teacher } \\
\text { and presentations, and } \\
\text { would take notes when } \\
\text { important points were } \\
\text { mentioned. She could } \\
\text { also have simple } \\
\text { interactions with the } \\
\text { teacher, asking and } \\
\text { answering questions }\end{array}$ & \\
& & course for a 3-year \\
& & & \\
& &
\end{tabular}


(continued)

\begin{tabular}{|c|c|c|c|}
\hline Time & Activities & Performance of Miss F & Notes \\
\hline $9: 10-11: 35$ & $\begin{array}{l}\text { Baking class with } \\
\text { visitors from other } \\
\text { schools. Under the } \\
\text { teacher's guidance, } \\
\text { Miss F helped prepare } \\
\text { the ingredients, } \\
\text { including sugar and } \\
\text { flour. Then, Miss F, } \\
\text { other classmates, and } \\
\text { teachers were divided } \\
\text { into groups of three } \\
\text { people. The teacher first } \\
\text { explained and } \\
\text { demonstrated how to } \\
\text { make cookies. Since the } \\
\text { basics have already } \\
\text { been covered before, he } \\
\text { focused on } \\
\text { demonstrating the } \\
\text { difficult part and details. } \\
\text { Afterwards, while Miss } \\
\text { F and her classmates } \\
\text { were putting what they } \\
\text { had learned into } \\
\text { practice, the teachers } \\
\text { answered their } \\
\text { questions and corrected } \\
\text { any mistakes }\end{array}$ & $\begin{array}{l}\text { The ingredients need to } \\
\text { be weighed accurately. } \\
\text { When preparing the } \\
\text { ingredients, Miss F was } \\
\text { focused and adjusted the } \\
\text { amount meticulously. } \\
\text { The teacher was pleased } \\
\text { that she could } \\
\text { immediately understand } \\
\text { any guidance provided, } \\
\text { and then make } \\
\text { necessary changes. } \\
\text { During the } \\
\text { demonstration by the } \\
\text { baking teachers, she } \\
\text { was attentive and would } \\
\text { raise questions when } \\
\text { she didn't understand. } \\
\text { During practice, we } \\
\text { could see that Miss F } \\
\text { was not only skillful and } \\
\text { well practiced, but also } \\
\text { well organized in that } \\
\text { she always cleaned up } \\
\text { the table after each step. } \\
\text { She also interacted with } \\
\text { the teacher, discussing } \\
\text { proper techniques, and } \\
\text { making necessary } \\
\text { corrections under the } \\
\text { guidance of the teacher. } \\
\text { From her eyes and } \\
\text { movements, I could see } \\
\text { that she was committed } \\
\text { and focused. The } \\
\text { teacher gave her a lot of } \\
\text { praise and } \\
\text { encouragement during } \\
\text { the class }\end{array}$ & $\begin{array}{l}\text { The morning baking } \\
\text { lessons were held } \\
\text { instead due to visits } \\
\text { from other schools. In } \\
\text { addition, a bakery } \\
\text { competition was to be } \\
\text { held in May of } 2017 \text { by } \\
\text { a food processing } \\
\text { company. One of the } \\
\text { sections would invite } \\
\text { people with intellectual } \\
\text { disabilities to do the } \\
\text { baking. So, they are } \\
\text { currently receiving } \\
\text { training for that }\end{array}$ \\
\hline
\end{tabular}


(continued)

\begin{tabular}{|c|c|c|c|}
\hline Time & Activities & Performance of Miss F & Notes \\
\hline $11: 35-12: 45$ & $\begin{array}{l}\text { Lunch and lunch break. } \\
\text { Lunch was in the } \\
\text { classroom. During the } \\
\text { break, a team of students } \\
\text { led by Miss F inspected } \\
\text { the work undertaken by } \\
\text { students, such as the } \\
\text { sanitation in staircases, } \\
\text { hallways, classrooms, } \\
\text { and teachers' offices in } \\
\text { the Happiness Building } \\
\text { and the Harmonious } \\
\text { Building. Then, after a } \\
\text { summary of their } \\
\text { performance, a star } \\
\text { student was } \\
\text { recommended }\end{array}$ & $\begin{array}{l}\text { Miss F chewed her food } \\
\text { slowly, and didn't look } \\
\text { around while eating. } \\
\text { The table was also kept } \\
\text { clean. After she } \\
\text { finished, she put her } \\
\text { meal box back into the } \\
\text { designated slot and also } \\
\text { helped the teachers } \\
\text { arranging the meal } \\
\text { boxes. She also brought } \\
\text { meals to teachers, and } \\
\text { politely said "Please } \\
\text { enjoy your meal." } \\
\text { During inspection, she } \\
\text { explained to her } \\
\text { classmates, with } \\
\text { patience and through } \\
\text { examples, how to } \\
\text { inspect the sanitary } \\
\text { conditions and how to } \\
\text { make comments. It } \\
\text { showcased her language } \\
\text { skills and clear line of } \\
\text { thinking. If students } \\
\text { failed to do a good job, } \\
\text { she pointed it out and } \\
\text { showed them how to do } \\
\text { it properly. She was } \\
\text { responsible and efficient } \\
\text { the entire time and had } \\
\text { communicated well } \\
\text { with her classmates. Her } \\
\text { classmates all think } \\
\text { highly of her }\end{array}$ & $\begin{array}{l}\text { As an inspector in her } \\
\text { school, Miss F is in } \\
\text { charge of overseeing the } \\
\text { work done by students. } \\
\text { Now that she is going to } \\
\text { graduate, she needs to } \\
\text { help the students who } \\
\text { will take over the job } \\
\text { familiarize themselves } \\
\text { with the process }\end{array}$ \\
\hline
\end{tabular}


(continued)

\begin{tabular}{|c|c|c|c|}
\hline Time & Activities & Performance of Miss F & Notes \\
\hline $12: 45-13: 25$ & $\begin{array}{l}\text { Psychology class. The } \\
\text { teacher checked their } \\
\text { homework and started a } \\
\text { new lesson }\end{array}$ & $\begin{array}{l}\text { As the teacher was } \\
\text { checking their } \\
\text { homework, Miss F } \\
\text { found that she didn't } \\
\text { finish all of it, so she } \\
\text { started to answer the } \\
\text { rest of the questions. By } \\
\text { the time the teacher } \\
\text { came to her, she had } \\
\text { already finished and } \\
\text { showed it to the teacher } \\
\text { who, upon inspection, } \\
\text { was pleased with her } \\
\text { work and asked her to } \\
\text { continue checking if } \\
\text { there were any mistakes. } \\
\text { Sitting in her chair, Miss } \\
\text { F seemed a bit bored, } \\
\text { playing with her pens or } \\
\text { arranging her books. } \\
\text { After a while, she } \\
\text { leaned back on her } \\
\text { chair, lost in thought. } \\
\text { When the teacher } \\
\text { returned to the podium, } \\
\text { ready to start the lesson, } \\
\text { Miss F shook herself up } \\
\text { and paid attention to } \\
\text { what the teacher was } \\
\text { saying while finding the } \\
\text { corresponding content } \\
\text { in her textbook }\end{array}$ & \\
\hline
\end{tabular}

(continued) 
(continued)

\begin{tabular}{|c|c|c|c|}
\hline Time & Activities & Performance of Miss F & Notes \\
\hline $13: 25-13: 35$ & Break & $\begin{array}{l}\text { Miss F sat in her seat } \\
\text { most of the time, either } \\
\text { having a rest on her } \\
\text { desk or arranging her } \\
\text { textbooks. As requested } \\
\text { by the teacher, she went } \\
\text { to fetch something from } \\
\text { another teacher. After } \\
\text { she returned, she had a } \\
\text { little chat with her } \\
\text { classmates before sitting } \\
\text { down, observing, and } \\
\text { keeping her fellow } \\
\text { students in order. For } \\
\text { example, having noticed } \\
\text { a student was running } \\
\text { and jumping around in } \\
\text { their classroom, she } \\
\text { stepped up and stopped } \\
\text { them }\end{array}$ & \\
\hline $13: 35-14: 20$ & $\begin{array}{l}\text { Chinese class. Dictation } \\
\text { exercise. Read an article } \\
\text { from the } \\
\text { textbook-Road Safety }\end{array}$ & $\begin{array}{l}\text { During dictation, Miss F } \\
\text { listened very carefully } \\
\text { to what the teacher was } \\
\text { saying and was able to } \\
\text { quickly write down the } \\
\text { correct answers. } \\
\text { Afterwards, she helped } \\
\text { the teacher collect the } \\
\text { answer books. } \\
\text { When she read a text out } \\
\text { loud, she was focused, } \\
\text { fluent, and accurate. She } \\
\text { was able to enunciate } \\
\text { and project her voice. } \\
\text { The teacher then raised } \\
\text { a question. Miss F was } \\
\text { very eager to answer, } \\
\text { but would also give } \\
\text { other students } \\
\text { opportunities and wait } \\
\text { for her turn if others } \\
\text { provided the wrong } \\
\text { answer. } \\
\text { Miss F was energetic } \\
\text { throughout the whole } \\
\text { class }\end{array}$ & \\
\hline
\end{tabular}


(continued)

\begin{tabular}{|c|c|c|c|}
\hline Time & Activities & Performance of Miss F & Notes \\
\hline $14: 30-15: 10$ & $\begin{array}{l}\text { Gardening class. } \\
\text { Exercise in replacing } \\
\text { the flowerpot and } \\
\text { removing weeds }\end{array}$ & $\begin{array}{l}\text { Miss F was the only } \\
\text { student in today's } \\
\text { gardening class, so she } \\
\text { had a one-on-one } \\
\text { opportunity to learn } \\
\text { from Mr. Li about how } \\
\text { to replace the flowerpot } \\
\text { and remove weeds. } \\
\text { They had smooth } \\
\text { interaction and } \\
\text { communication, with } \\
\text { occasional jokes thrown } \\
\text { in. Mr. Li had a good } \\
\text { sense of humor and } \\
\text { made her laugh } \\
\text { sometimes. The general } \\
\text { atmosphere was } \\
\text { relaxing. As observed, } \\
\text { Miss F was well } \\
\text { practiced, and able to } \\
\text { adjust her techniques } \\
\text { per instruction. By the } \\
\text { end of the class, she has } \\
\text { already finished two pot } \\
\text { plants }\end{array}$ & $\begin{array}{l}\text { Gardening is an } \\
\text { individualized optional } \\
\text { course provided by this } \\
\text { school, which Miss F } \\
\text { has chosen for this } \\
\text { semester }\end{array}$ \\
\hline $15: 20-16: 00$ & $\begin{array}{l}\text { Indoor exercises and } \\
\text { activities. Play flying } \\
\text { chess }\end{array}$ & $\begin{array}{l}\text { While playing flying } \\
\text { chess, Miss F showed } \\
\text { good teamwork with her } \\
\text { classmates. She was } \\
\text { patient and waited for } \\
\text { others to finish their } \\
\text { moves. If they didn't } \\
\text { know their next move, } \\
\text { she would give them } \\
\text { tips and assistance. } \\
\text { When she took a break } \\
\text { from the game, she } \\
\text { walked around the } \\
\text { classroom, took in what } \\
\text { others were doing, and } \\
\text { made occasional } \\
\text { inquiries. She was polite } \\
\text { and didn't cause any } \\
\text { disruptions }\end{array}$ & \\
\hline
\end{tabular}




\begin{tabular}{|c|c|c|c|}
\hline Time & Activities & Performance of Miss F & Notes \\
\hline After school. & $\begin{array}{l}\text { She collected her stuff } \\
\text { and said goodbye to her } \\
\text { teacher }\end{array}$ & $\begin{array}{l}\text { Miss F put her } \\
\text { stationery and textbooks } \\
\text { back in order and tidied } \\
\text { up her desk and } \\
\text { drawers. She was well } \\
\text { organized. She looked } \\
\text { around the classroom, } \\
\text { waited for a while after } \\
\text { everyone had gone, and } \\
\text { asked the teacher if any } \\
\text { assistance was needed. } \\
\text { After saying her } \\
\text { goodbyes, she walked } \\
\text { towards the school gate }\end{array}$ & \\
\hline
\end{tabular}

Translated by Min Cui

Open Access This chapter is licensed under the terms of the Creative Commons AttributionNonCommercial-NoDerivatives 4.0 International License (http://creativecommons.org/licenses/bync-nd/4.0/), which permits any noncommercial use, sharing, distribution and reproduction in any medium or format, as long as you give appropriate credit to the original author(s) and the source, provide a link to the Creative Commons license and indicate if you modified the licensed material. You do not have permission under this license to share adapted material derived from this chapter or parts of it.

The images or other third party material in this chapter are included in the chapter's Creative Commons license, unless indicated otherwise in a credit line to the material. If material is not included in the chapter's Creative Commons license and your intended use is not permitted by statutory regulation or exceeds the permitted use, you will need to obtain permission directly from the copyright holder.

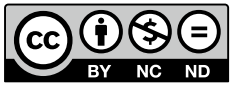

